\title{
Clinical features of Senior-Loken syndrome with IQCB1/NPHP5 mutation in a Filipino man
}

\author{
Harold Henrison C. Chiu ${ }^{1} * \oplus$, Ma. Sergia Fatima P. Sucaldito ${ }^{1 \oplus}$, Ebner Bon G. Maceda ${ }^{2 \oplus}$, Jan Andre S. Montemayor ${ }^{3 \oplus}$, \\ Diana R. Tamondong-Lachica ${ }^{1 \oplus}$ \\ ${ }^{1}$ Department of Medicine, Philippine General Hospital, University of the Philippines Manila, Manila, Philippines \\ ${ }^{2}$ Division of Clinical Genetics, Department of Paediatrics, Philippine General Hospital, University of the Philippines Manila, Manila, Philippines \\ ${ }^{3}$ Division of Nephrology, Department of Medicine, Philippine General Hospital, University of the Philippines Manila, Manila, Philippines
}

The Senior-Loken syndrome was first described in 1961 as an oculo-renal disease consisting of familial juvenile nephronophthisis and Leber congenital amaurosis. It is a rare autosomal recessive disorder with a prevalence of 1:1,000,000 caused by mutations in nine genes (NPHP 1-8 and NPHP 10). Ocular manifestations (e.g., photophobia, nystagmus, and extreme hyperopia) occur within the first few years of life while renal manifestations (e.g., formation of multiple cysts impairing kidney function and end-stage renal disease) appear in late childhood to adolescence. Here, we report a case of a Filipino male presenting with rotatory nystagmus and progressive deterioration of vision since childhood. He had congenital amaurosis and juvenile nephronophthisis that progressed to end stage renal disease by age 19. All laboratory and imaging findings were consistent with chronic kidney disease. Molecular genetic testing of ciliopathy-related genes was performed revealing a homozygous mutation in exon 11 of the IQCB1/NPHP5 gene, c.1090C $>$ T (p.Arg364*). This sequence change created a premature translational stop signal resulting in a truncated protein product, nephrocystin-5 and its consequent loss of function. His symptoms eventually improved with initiation dialysis. The prognosis of Senior-Loken syndrome remains dismal and a high index of suspicion, early diagnosis and timely intervention of renal complications are warranted.

Key words: Ciliopathies, IQCB1 protein, human, Leber congenital amaurosis, Nephronophthisis, familial juvenil, Senior Loken syndrome.

\section{Introduction}

The Senior-Loken syndrome (SLSN) was first concurrently described by Senior et al. [1] and Loken et al. [2] in 1961 as a combination of familial juvenile nephronophthisis and Leber congenital amaurosis. It is a rare autosomal recessive oculo-renal disease with a prevalence of 1:1,000,000 [3,4] belonging to the group of rare diseases called nephronophthisis (NPHP, OMIM 2561000).
Presently, mutations in nine genes (NPHP 1-8 and NPHP 10) have been observed in patients with SLS [4]. IOCB1/NPHP5 mutations are the major cause of the SLSN type 5 (SLSN5, OMIM 609254) presenting as the classic features of retinopathy and end stage renal disease. Here, we report a case of SLSN in a Filipino man with the IQCB1/NPHP5 mutation. To date, there have been no on SLSN from Filipino patients.

Received: 16 March 2020, Revised: 31 March 2020, Accepted: 2 April 2020, Published: 30 June 2020

${ }^{*}$ Corresponding author: Harold Henrison C. Chiu, M.D. (iD https://orcid.org/0000-0002-2021-7843

Department of Medicine, Philippine General Hospital, University of the Philippines Manila, Taft Avenue, Ermita, Manila, Philippines.

Tel: +63-9258731130, Fax: +63285548400, E-mail: harold.c.chiu@gmail.com

Conflict of interest: The authors declare that they do not have any conflicts of interest.

(C) This is an open-access article distributed under the terms of the Creative Commons Attribution Non-Commercial License (http://creativecommons.org/licenses/by-nc/4.0/) which permits unrestricted non-commercial use, distribution, and reproduction in any medium, provided the original work is properly cited.

(c) Copyright 2020 by the Korean Society of Medical Genetics and Genomics 


\section{Case}

A 19-year old male was admitted at our emergency room for intractable vomiting, dysgeusia, epigastric pain, and generalized weakness. He was the eldest of three siblings born to a healthy non-consanguineous couple of Filipino descent (Fig. 1). Both parents and two older sisters were completely asymptomatic. He had persistent rotatory nystagmus and progressive deterioration of vision since childhood, with current visual acuity of light perception for both eyes. He attended special education until the second grade, and subsequently entered the regular education system but still requiring assistance in schoolwork from his parents. Important physical examination findings include the following: elevated blood pressure of 140-150 $\mathrm{mmHg}$ systolic and $90-100 \mathrm{mmHg}$ diastolic, body weight less than 3rd percentile for age, persistent rotatory nystagmus of both eyes, and pale palpebral conjunctivae.

Relevant laboratory findings on admission showed a serum creatinine level of 1,195 $\mu \mathrm{mol} / \mathrm{L}$, blood urea nitrogen level of $28.57 \mathrm{mmol} / \mathrm{L}$, serum sodium of $106 \mathrm{mmol} / \mathrm{L}$, serum potassium of $5.6 \mathrm{mmol} / \mathrm{L}$ and normocytic, normochromic anaemia (haemoglobin of $66 \mathrm{~g} / \mathrm{L}$ ). Imaging of the kidneys using computed tomography revealed bilaterally small kidneys consistent with renal parenchymal disease, and two fairly defined hypodensities on the left kidney. Fundoscopy of both eyes revealed pale optic discs, attenuated blood vessels and diffuse bony spicules compatible with Leber congenital amaurosis. The glaring ophthalmologic symptoms (persistent nystagmus and light percep-

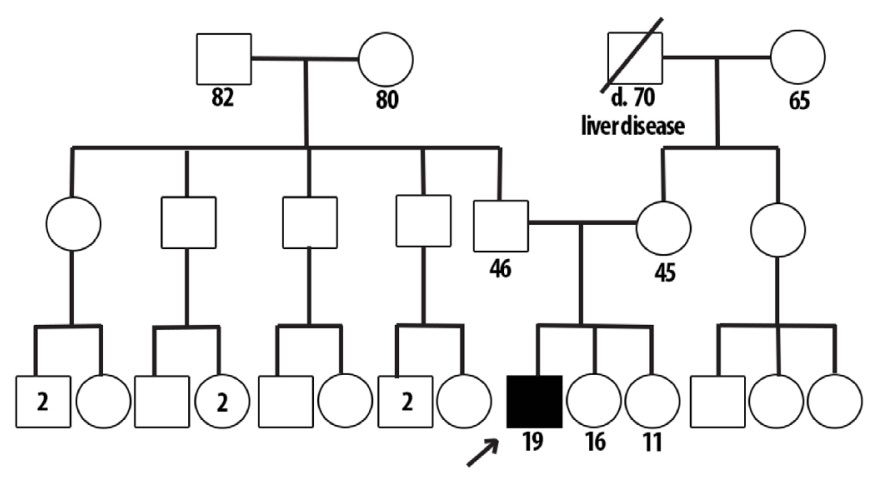

Fig. 1. The three-generation pedigree of the patient. tion on visual acuity) since childhood as well as the fundoscopic findings of diffuse retinal atrophy led our team to suspect an oculo-renal genetic syndrome, of which the most consistent would be a nephronophthisis. Buccal DNA was extracted, and sequence analysis and deletion/duplication testing of the 102 genes (Invitae Ciliopathies Panel) was performed revealing a homozygous mutation in the IOCB1 gene (Table 1) consistent with SLSN5. This sequence change creates a premature translational stop signal (p.Arg364*) in the IOCB1 gene therefore, resulting in either an absent or truncated protein product of nephrocystin- 5 and hence, its consequent pathogenic loss of function [3].

Our patient underwent haemodialysis and blood transfusion with gradual improvement of his condition. However, visual symptoms did not improve. He was successfully discharged after one week of admission and is currently on regular follow-up with our outpatient service where post-genetic testing counselling was rendered to both the patient and his parents. During this follow-up, he was seen ambulatory with an improved overall well-being.

\section{Discussion}

The SLSN5 caused by mutations in the NPHP5/ICOB1 gene was first identified by Otto et al. [3] in 2005. The NPHP5/ICOB1 gene, codes for a protein, nephronocystin-5, also known as the IQ calmodulin-binding motif-containing protein 1 . The mutation leads to the formation of a truncated version of nephrocystin-5, which interacts directly with calmodulin and forms a complex with retinitis pigmentosa GTPase regulator (RPGR). Both nephrocystin and RPGR are localized in the ciliary apparatus of photoreceptor cells in the retina and renal epithelial cells, providing a basis for the oculo-renal syndrome observed when NPHP5 is mutated [4]. Patients with SLSN5 invariably develop early-onset retinitis pigmentosa and atrophy, with variable onset of renal manifestations, eventually leading to end stage renal disease from the first to third decade [4].

While not yet reported in the Philippines, SLSN5 has been reported in various Asian populations [5-12]. Notably, in the two studies of siblings, of Chinese [9] and Kuwaiti [10] descent, respectively, both presented with many similar characteristics

Table 1. Genetic testing results of the patient

\begin{tabular}{clll}
\hline Gene & \multicolumn{1}{c}{ Variant } & Zygosity & Classification \\
\hline IQCB1 & $\mathrm{c} .1090 \mathrm{C}>\mathrm{T}(\mathrm{p}$. Arg364*) & Homozygous & Pathogenic \\
CCDC65 & $\mathrm{c} .930 \mathrm{~A}>\mathrm{T}(\mathrm{p} . \mathrm{Gln} 310 \mathrm{His})$ & Heterozygous & Uncertain significance \\
WDR34 & $\mathrm{c} .1565 \mathrm{G}>\mathrm{A}(\mathrm{p}$. Arg522Gln) & Heterozygous & Uncertain significance \\
\hline
\end{tabular}


Table 2. Summary of clinical characteristics of reported cases of Senior-Loken syndrome in patients of Asian descent

\begin{tabular}{|c|c|c|c|c|}
\hline Report & Age (yr) /sex & Ethnicity & Manifestations & Consanguinity \\
\hline \multirow[t]{2}{*}{ Clarke et al. [5] } & Sibling A: 10/F & Indian & $\begin{array}{l}\text { Leber congenital amaurosis } \\
\text { Mild to moderate sensorineural hearing loss }\end{array}$ & $(+)$ \\
\hline & Sibling B: 8/M & & End-stage renal disease & \\
\hline AlFadhel and AIAmir [6] & $11 / F$ & Arabic & $\begin{array}{l}\text { Retinitis pigmentosa } \\
\text { End-stage renal disease }\end{array}$ & $(+)$ \\
\hline Haghighi et al. [7] & $26 / M$ & Iranian & $\begin{array}{l}\text { Retinitis pigmentosa } \\
\text { End-stage renal disease }\end{array}$ & $(+)$ \\
\hline Aggarwal et al. [8] & 19/M & Indian & $\begin{array}{l}\text { Retinitis pigmentosa } \\
\text { End-stage renal disease } \\
\text { Madarosis } \\
\text { Small hands }\end{array}$ & $(-)$ \\
\hline \multirow[t]{2}{*}{ Tong et al. [9] } & Sibling A: 16/F & Chinese & Leber congenital amaurosis & $(-)$ \\
\hline & Sibling B: 12/F & & End-stage renal disease & \\
\hline \multirow[t]{2}{*}{ Marafie and Mulla [10] } & Sibling A: 18/F & Kuwait & $\begin{array}{l}\text { Leber congenital amaurosis } \\
\text { End-stage renal failure }\end{array}$ & $(+)$ \\
\hline & Sibling B: 9/M & & $\begin{array}{l}\text { Leber congenital amaurosis } \\
\text { End-stage renal failure }\end{array}$ & \\
\hline Kaur et al. [11] & $9 / F$ & Indian & $\begin{array}{l}\text { Retinitis pigmentosa } \\
\text { End-stage renal disease }\end{array}$ & $(-)$ \\
\hline Khairil-Ridzwan et al. [12] & $14 / \mathrm{M}$ & Chinese & $\begin{array}{l}\text { Coat's disease } \\
\text { End-stage renal disease }\end{array}$ & $(-)$ \\
\hline Index patient & 19/M & Filipino & $\begin{array}{l}\text { Leber congenital amaurosis } \\
\text { End-stage renal failure }\end{array}$ & $(-)$ \\
\hline
\end{tabular}

F, female; M, male.

to our patient: Leber congenital amaurosis, growth retardation, anemia, polycystic kidney disease, and development of end-stage renal disease in the second decade of life. Different mutations in the same gene have also been observed in Indian [5], Arabian [6], Iranian [8], and Chinese [9] families, notably from consanguineous lineages, which showed a highly variable onset of retinitis pigmentosa (ranging from birth to teenage years) with end-stage renal disease developing from the first to the second decade (Table 2) [5-12].

The pathogenesis of SLSN can be explained by the ciliary theory of polycystic kidney diseases. A mutation in a single NPHP gene is enough to cause the syndrome, indicating that their protein products are necessary for renal function. NPHP1 and NPHP2/inversion were the first genes to be localized in the primary cilia of renal epithelial cells [13], and resulting mutations in various components of cilia, basal bodies, and centrosomes have been shown to cause cystic kidney diseases. SLSN demonstrates that these highly-conserved proteins play a vital role in the functioning of cilia in other parts of the body notably the sensory system. Ciliated receptors process a variety of stimuli, including photosensation, mechanosensation, osmosensation, and olfactory sensation, hence the pathogenesis of these mutations stems from the inability of cilia to receive or process these cues [14].

The prognosis of SLSN primarily depends on early diagnosis and a high index of suspicion, it should be included in the differential diagnoses for young patients presenting with visual decline and progressive renal failure; and timely management of the renal complications, which is the major cause of mortality. However, there are currently no available treatment options to prevent progression of visual loss.

\section{Acknowledgements}

We would like to extend our gratitude to our patient and his family for participating in our research study.

\section{References}

1. Senior B, Friedmann Al, Braudo JL. Juvenile familial nephropathy with tapetoretinal degeneration. A new oculorenal dystrophy. Am J Ophthalmol 1961;52:625-33.

2. Loken AC, Hanssen O, Halvorsen S, Jolster NJ. Hereditary renal dysplasia and blindness. Acta Paediatr 1961;50:177-84.

3. Otto EA, Loeys $B$, Khanna $H$, Hellemans J, Sudbrak R, Fan $S$, et al. Nephrocystin-5, a ciliary IO domain protein, is mutated in Senior- 
Loken syndrome and interacts with RPGR and calmodulin. Nat Genet 2005;37:282-8.

4. Hildebrandt $F_{1}$ Attanasio M, Otto E. Nephronophthisis: disease mechanisms of a ciliopathy. J Am Soc Nephrol 2009;20:23-35.

5. Clarke MP, Sullivan TJ, Francis C, Baumal R, Fenton T, Pearce WG. Senior-Loken syndrome. Case reports of two siblings and association with sensorineural deafness. Br J Ophthalmol 1992;76:171-2.

6. AlFadhel M, AlAmir A. Senior-Loken syndrome in a Saudi child. Saudi J Kidney Dis Transpl 2008;19:443-5.

7. Haghighi A, Al-Hamed M, Al-Hissi S, Hynes AM, Sharifian M, Roozbeh $J$, et al. Senior-Loken syndrome secondary to NPHP5/IOCB1 mutation in an Iranian family. NDT Plus 2011;4:421-3.

8. Aggarwal HK, Jain D, Yadav S, Kaverappa V, Gupta A. Senior-Loken syndrome with rare manifestations: a case report. Eurasian J Med 2013:45:128-31.

9. Tong H, Yue Z, Sun L, Chen H, Wang W, Wang H. Clinical features and mutation of NPHP5 in two Chinese siblings with Senior-Løken syn- drome. Nephrology (Carlton) 2013;18:838-42.

10. Marafie MJ, Mulla FA. Senior-Loken syndrome: a novel NPHP5 gene mutation in a family from Kuwait. Egypt J Med Hum Genet 2014;15:203-7.

11. Kaur A, Dhir SK, Goyal G, Mittal N, Goyal RK. Senior Loken Syndrome. J Clin Diagn Res 2016;10:SD03-4.

12. Khairil-Ridzwan KK, Azian A, Hanizasurana H, Shatriah I. Exudative retinal detachment due to coats disease in a teenager with senior-loken syndrome: case report and review of literature. Cureus 2019;11:e4460.

13. Otto EA, Schermer B, Obara T, O'Toole JF, Hiller KS, Mueller AM, et al. Mutations in INVS encoding inversin cause nephronophthisis type 2 , linking renal cystic disease to the function of primary cilia and leftright axis determination. Nat Genet 2003;34:413-20.

14. Benzing T, Walz G. Cilium-generated signaling: a cellular GPS? Curr Opin Nephrol Hypertens 2006;15:245-9. 